\author{
Anna Kuśmirek \\ Cardinal Stefan Wyszyński University in Warsaw \\ ORCID o0oo-0002-1736-9897
}

\title{
The Phenomenon of Targumism in the Aramaic Version of the First and Second Books of Chronicles ${ }^{1}$
}

\begin{abstract}
The main objective of the article is to show the features of the Aramaic translation of the First and the Second Books of Chronicles, which belongs to late Targums. The work presents the main data related to the authority, date and origin of the Targum and its manuscripts, as well as a review of major translation techniques and the method of rabbinic interpretation, which are all important elements of targumism. Linguistic changes, as well as cultural and religious ones, conditioned by various processes that occurred in the community of believers in $\mathrm{YHWH}$ over the centuries, were reflected in a variety of interpretative tendencies.
\end{abstract}

Keywords: $1-2$ Books of Chronicles, Writings, Targum Chronicles, Aramaic translation

$\mathrm{T}$ he main task of the Aramaic biblical translations was the appropriate rendering of the Hebrew text into Aramaic due to the progressive spread of this language among the Jews. However, the role of the translator - targumist (meturgeman) was not limited only to the translation of the original text, but also consisted in explaining it with the use of the accepted elements of Jewish exegesis. In the targums, the sacred text was supplemented, expanded by the translator, who, using various techniques of

${ }^{1}$ This article is a corrected version of the article published in Polish: Anna Kuśmirek, "Zjawisko targumizmu w aramejskiej wersji Pierwszej i Drugiej Księgi Kronik," Collectanea Theologica 89 (2019) no. 4, 221-248. Translated from Polish by Maciej Górnicki. 
adaptation and updating, tried to adjust it to the reception capabilities of the current audience and the needs of the community. This process is part of the phenomenon of targumism, or targumization. In the context of research on the Targum of the Song of Songs, an attempt has been made to clarify both notions. ${ }^{2}$ According to Waldemar Chrostowski, both phenomena should be distinguished from each other. While the phenomenon of targumism concerned mainly the rendering of the Hebrew text into Aramaic, targumization encompasses the complex long-term process of creating targums using the existing targums based on and the various linguistic, cultural, and religious changes they contained, which found expression in a multitude of interpretative tendencies. ${ }^{3}$

In relation to the Aramaic translation of the Books of Chronicles, the questions will be raised: In what setting environment were the Targums for these books written, and what influence might this have had on their message? In contrast to other targums, whose translations into Polish have already been worked on (Targum Neofiti, Targum Jonathan), ${ }^{4}$ and unlike the studies on the Aramaic versions, such as the Targum of the Pentateuch, ${ }^{5}$ Targum Jonathan to the Prophets, ${ }^{6}$ or the most popular Targum of the Song of Songs ${ }^{7}$ and Targum Ruth, ${ }^{8}$ which belong to the collection of Targums of the Writings, no studies have been carried out on the Targum of Chronicles. The aim of this article is to present the main translation

2 This phenomenon was described in Polish by M. Baraniak, Zjawisko targumizacji, Warszawa 2013.

${ }^{3}$ W. Chrostowski, rev.: M. Baraniak, Zjawisko targumizacji.

${ }^{4}$ M. Wróbel (transl. and ed.), Biblia Aramejska. Targum Neofiti 1. Księga Rodzaju, vol. 1; M. Wróbel, Biblia Aramejska Targum Neofiti 1. Księga Wyjścia, vol. 2 .

${ }^{5}$ For publication on the interpretation of Genesis in the targums see, e.g.: T. Niedźwiecki, Joseph's Two Garments; A. Kuśmirek, Księga Rodzaju 1-11; A. Kuśmirek, Jacob's Blessing (Gen 49,1-28) in Targumic Interpretation.

${ }^{6}$ A. Kuśmirek, Księga Nahuma; A. Kuśmirek, Aramejska wersja Księgi Amosa.

7 See, e.g., M. Baraniak, Zjawisko targumizacji; K. Bardski, Świątynia Salomona; K. Bardski, Niewola babilońska; K. Bardski, Eschatologia mesjańska. Apart from the already mentioned monograph on Tg. Cant., M. Baraniak is also the author of, among others, the article Motyw miasta.

${ }^{8}$ A. Kuśmirek, Twój naród będzie moim narodem, twój Bóg będzie moim Bogiem - wyznanie Rut w interpretacji targumu (Rt 1,16-17). 
techniques and elements of Jewish exegesis present in the Aramaic version of the Book of Chronicles. In light of the discussion presented on the phenomenon of targumism and targumization, this article assumes that targumization is an integral element of the phenomenon of targumism.

\section{The status of the First and Second Books of Chronicles in Judaism}

First and Second Chronicles and their Aramaic translation were not among popular books, either in ancient or modern times. In the Hebrew Bible, the two books form an inseparable whole and bear the Hebrew name dibrê hayyamîm (literally "words of the days," "events of the times"), which points to the content of the book. Thus, the Book of Chronicles covers the history of Israel from Adam to the decree of Cyrus (538) and the times of restoration after the exile. In the Septuagint, both works of the Chronicles is entitled Paraleipomenōn tōn basileōn Iouda (literally, "the things forsaken of the kings of Judah"). Here, they are divided into two parts, ${ }^{9}$ and was placed right after the Books of Kings. The name "Chronicles" comes from St. Jerome, who assigned them the Latin name Chronicon totius divinae historiae ("chronicles of all sacred history"). ${ }^{10}$ The title from the LXX itself may suggest that the Chronicles were marginalized and regarded rather as a supplement to the Books of Samuel and Kings rather than a separate unit. ${ }^{11}$ The contents of these books cover the history of ancient Israel from Adam to the restoration of Judah after the Babylonian exile.

In the canon of the Hebrew Bible, Chronicles belongs to the third set of books, called the Writings (Hebrew: kẹtûbîm). ${ }^{12}$ Although it

${ }^{9}$ In $\mathrm{BH}$ the division was accepted in the $15^{\text {th }}$ century. Cf. R.W. Klein, Chronicles, Book of 1-2, 992.

${ }^{10}$ V.P. Hamilton, Handbook on the Historical Books, 477.

${ }^{11}$ M.J. Selman, 1 Chronicles, 20.

${ }^{12}$ In the two most important manuscripts, namely the Codex Petropolitanus (B19A), dating to the ninth century, and the Codex Aleppensis (A), dating to the tenth century, after the collection of the Prophets, Chronicles comes first, followed only by Psalms, Job, Proverbs, Ruth, Song of Songs, Kohelet, Lamentations, Esther 
presents details of events as far back as the time of Ezra and Nehemiah, in the Talmudic tractate Baba Bathra (b. B. B. 14b) it is listed after Ezra-Ne at the very end of the list of the Writings.

According to Jewish tradition, Ezra is the author of part of the book: "Ezra wrote the book which bears his name, and the genealogies of the Chronicles going back to his time" (b. B. B. 15a); a little further on in the same treatise it is stated that the remaining part of the work was completed by Nehemiah.

Unlike the collection of Five Scrolls (Hāmēšs Mĕgillôt), which over time were assigned to particular Jewish feasts ${ }^{13}$ and were therefore read in synagogue, the Books of Chronicles was not associated with any festival or synagogue liturgy. However, in the Mishna there are some references to the reading of Chronicles. ${ }^{14}$ The Mishnah mentions that fragments of Chronicles (as well as Ezra, Job and Daniel) were read out to the high priest, as he was not proficient in reading the Scriptures. It was supposed to help him not to fall asleep before the rites of the Day of Atonement began (m. Yoma 1,6). ${ }^{15}$ Nevertheless, it can be assumed that ordinary recipient could get to know the message of the Hebrew Chronicles at Jewish school (beth midrash) or in a private study of Scripture.

In exegetical Jewish literature, references to the Book of Chronicles can also be found in midrashic literature (Midrash

Daniel and Ezra-Nehemiah. This may have been because, since the figure of David plays such an important role in it, it provides a good introduction to the book whose authorship is attributed to him. See J. A. Sanders, Canon: Hebrew Bible, 840.

${ }^{13}$ Song of Songs (Pesach), the Book of Ruth (Shavuot), Lamentations (9 Av), the Book of Kohelet (Sukkot) and the Book of Esther (Purim). The tradition attributing these books to festivals dates back to at least the 6th century, although it is possible that its first manifestations took place earlier.

${ }^{14}$ See I. Kalimi, History of Interpretation. See also I. Kalimi, The Retelling of Chronicles, 141-154.

15 The treatise on the Sabbath, on the other hand, shows that the reading of 1-2 Chr may have been part of the liturgy in at least one centre of Judaism, namely Nahardei, where the reading taken from the Scriptures constituted a kind of haftarah or minhah on the Sabbath (b. Shab. 116b). However, according to J. Mann, this entire passage in b. Shab. "concerns the study in the bet hammidrash and not the synagogue liturgy, as R. Isaiah di Trani rightly observes." This position leads some scholars to take the position that Chronicles may have been accepted into the canon at some later stage. This discussion is cited by J. Stanley McIvor, The Targum Chronicles, 12. 
Rabba), in commentaries (LevR 1:3; cf. RuthR 2:1), where Rab states: "The Book of Chronicles was given to be explained only by means of midrash." In addition, scholars argue that there may have been a set of midrashic interpretations based on Chronicles, citing in support of this thesis, for example, the passage b. Pes. 62b: "From the day when the Book of the Genealogy was hidden, the strength of the sages weakened, and the light of their eyes dimmed. Mar Zutra said: 'Between 'Azel' and 'Azel' [i.e., between $1 \mathrm{Chr}$ 8:38 and 1 Chr 9:34] have been burdened with four hundred camels of exegetical interpretations'."16

A clue to the nature of this approach is found in b. Meg. 13a, where the exegesis of $1 \mathrm{Chr} 4: 18$ (it connects the names of various characters and the meaning contained in them with the person of Moses) is preceded by such a remark: "All your words are a unity, and we know how to find their inner meaning." 17 This statement suggest that the names of various characters can be considered to refer to one and the same person, if the exegetical comments require so.

Fragments of Chronicles are also present in homilies delivered in synagogues (pesiktas), such as Pesikta de Rab Kahana (5th century) and Pesikta Rabbati (6th-7th centuries). ${ }^{18}$ Although 1-2 Chr did not happen to be read in the liturgy, some of its passages seeped into it, yet in a different way. The lack of reading of Chronicles in the Jewish liturgical tradition contributed to the limited knowledge of the Targum of Chronicles. ${ }^{19}$ References to this Targum are also lacking in medieval writers. Scholars point out that Rashi (1045-1105) did not know any Targum to the Writings. This also holds true with regard to David Kimchi (1160-1235), who left commentaries on many books of the Bible, including the Former and Latter Prophets, and also wrote the first commentary on Chronicles

16 J. Stanley McIvor, The Targum Chronicles, 12; see also: I. Kalimi, The Retelling of Chronicles, 146-148.

${ }^{17}$ I. Kalimi, The Retelling of Chronicles, 150.

18 J. Stanley McIvor, The Targum Chronicles, 13.

${ }^{19}$ P. Churgin, The Targum to Hagiographa, 236. 
does not mention their Targum even once. ${ }^{20}$ Also according to Elias Levita (1469-1549), no Targum of Chronicles has ever been written. ${ }^{21}$ Isaac Kalimi points out, however, that fragments of the Targum of Chronicles were found in the 19th century in the Cairo genizah, which may indicate that, unlike in the medieval Europe, this work was known in Egypt. ${ }^{22}$

\section{Targum Chronicles - manuscripts and editions}

Early editions of the Rabbinic Bible did not include the Targum of Chronicles, and it is missing from both the first edition of the Mikraot Gedolot prepared by Felix of Prato and the second edition of Jacob ben Hayyim, which were printed by Daniel Bomberg in Biblia Rabbinica in 1517 and 1525 , respectively. ${ }^{23}$ It is also missing alongside the Hebrew text in Biblia sacra polyglotta published in London by Brian Walton between 1654 and 1657. ${ }^{24}$ Targum Chronicles appears in the Hagiographa Chaldaice, published by Paul de Lagarde in Leipzig in 1873, who used the Erfurt manuscript, with the aid of the Cambridge manuscript and another unspecified codex.

Only three manuscripts with the text of the Targum of the First and Second Chronicles have survived to our times: ${ }^{25}$

1) Vatican (V), Cod. Vat. Urb. Ebr. 1, dated 1294, published by Roger Le Déaut and Jacques Robert, who made a faithful transcription of the Vatican manuscript and published it in two

${ }^{20}$ In discussing passages in 1-2 Chr that have parallels in 1-2 Sam and 1-2 Kings, Kimchi quotes Tg. 1-2 Sam. and Tg. 1-2 Kgs., J. Stanley McIvor, The Targum Chronicles, 14.

${ }^{21}$ Ibid.

${ }^{22}$ I. Kalimi, The Retelling of Chronicles, 158.

${ }^{23}$ I. Kalimi, The Retelling of Chronicles, 158. See also ibid., 119-120.

${ }^{24}$ J. Stanley McIvor, The Targum Chronicles, 14.

25 The fourth manuscript was located in Dresden, but was destroyed in 1945. See P.S. Alexander, Targum, Targumim, 328; I. Kalimi, The Retelling of Chronicles, 155; J. Stanley McIvor, The Targum Chronicles, 14-15. 
volumes with an introduction, text, footnotes and French translation. ${ }^{26}$

2) Erfurt (E), Ms. Or. fol. 1210 and 1211, dated 1343, is which is held by the Deutsche Staatsbibliothek in Berlin. This voluminous manuscript was published in two volumes with an introduction, text, footnotes and Latin translation by Matthäus Friedrich Beck as Paraphrasis Chaldaica I Libri Chronicorum, Augsburg 1680; also Paraphrasis Chaldaica II Libri Chronicorum, Augsburg 1683.

3) Cambridge manuscript (C), Ms. Or. Ee. 5.9, dated 1347, held at Cambridge University, was published by David Wilkins, who completed the work had been initiated by Samuel Clericus under the title Paraphrasis Chaldaica in Librum Priorem et Posteriorem Chronicorum Auctore Rabbi Josepho Rectore Academicae in Syria..., Amsterdam 1715.

In the 20th century, a critical study of the Targum Chronicles was published by Alexander Sperber, who relied mainly on the Erfurt manuscript published by Matthäus Friedrich Beck and an edition by Paul de Lagarde. ${ }^{27}$

According to Le Déaut, manuscripts: E, C and V come from a common source, although not necessarily from the same document. Among other things, they show a correspondence in minor matters, e.g., in terms of specific word constructions, but in other places different forms of the same words are present. After more thorough research, Le Déaut concluded that there were more complex relationships between these manuscripts. Indeed, he found that $\mathrm{C}$ and $\mathrm{V}$ share more features with each other than with $\mathrm{E} .^{28}$

${ }^{26}$ Targum des Chroniques. The Hebrew text has been made available in an electronic version: Comprehensive Aramaic Lexicon Project (CAL), Targum Chronicles.

${ }^{27}$ The Bible in Aramaic, 3-119. Lagarde's and Sperber's editions are almost identical. In addition to the text, Sperber adds notes on the age and place of origin of this document in his publication, and next to the text of Tg. 1-2 Chr. places parallel texts from Tg. 1-2 Sam. and Tg. 1-2 Kgs in adjacent columns.

${ }^{28}$ He cites the following examples to confirm this: the verb "to send" in C and $\mathrm{V}$ is written $\check{s} d r$, while E gives $\check{s} l h . \mathrm{C}$ and $\mathrm{V}$ insert alternative variants in the text (very similar, by the way, e.g., Tg. 1 Chr. 11:16; 18:13; 21:27), whereas this is not the case in E. C and V use the same specific verbal constructions (e.g., Tg. $1 \mathrm{Chr}$. 10:7; 28:9.12; Tg. 2 Chr. 2:11), use the same terminology (Tg. 2 Chr. 4:16; 14:5), 


\section{Author, date, and origin}

Traditionally, the authorship of the Targum of the Writings, including the Targum of Chronicles, is attributed to one of the Amoraite from the third generation of Babylonian scholars, Rab Joseph the Blind of Pumbedita (290-320). ${ }^{29}$ The hypothesis he was the author of the Targum of the Writings was Rab Joseph was questioned already in the Middle Ages, and was also rejected by Elias Levita.

Like Leopold Zunz (1794-1886), ${ }^{30} 20^{\text {th }}$ century scholars also assume that, like other Targums of the Writings, the Chronicles Targum may have originated in the late Talmudic era, but it did not take its final form until the $8^{\text {th }}$ century. ${ }^{31}$ This work developed gradually as the product of several generations of targumists. It is also possible that the author of the Targum Chronicles made use various ancient sources, which he received, processed and reshaped, while the editing itself did not undergo such development. ${ }^{32}$ Modern scholars draw attention to the fact that the Targum of Chronicles was written in the Palestinian dialect of the Aramaic, as is the case with the Jerusalem Targums (also known as the Palestinian Targums), ${ }^{33}$ and could therefore have originated in

have the same dittography (Tg. 2 Chr. 18:33), similarly the same variants (Tg. 2 Chr. 33:8; 36:10). At the same time, Le Déaut points out the differences that occur in $\mathrm{C}$ and V (Tg. 1 Chr. 3:12; 9:40; Tg. 2 Chr. 7:6; 10:7), and some paraphrases in the two manuscripts are constructed differently (Tg. 1 Chr. 2:17-18; 4:24).

${ }^{29}$ Wilkins ascribes it to the academy in Syria, while Rosenberg and Kohler regard this as an error and argue for the academy at Sura. To Rab Yosef the Blind (d. 320), the treatise Bawa Kamma attributes the title of "commentator," but it seems improbable that an amoraite from Babylonia would be the author of a targum that emphasizes Palestinian affairs so strongly. J. Stanley McIvor, The Targum Chronicles, 14.

${ }^{30}$ L. Zunz, Die gottesdienstlichen Vorträge, 68 note d.

${ }^{31}$ R. Le Déaut, J. Robert, Targum des Chroniques, 24-28. Similarly, J. Stanley McIvor, The Targum Chronicles, 15.

${ }^{32}$ I. Kalimi, The Retelling of Chronicles, 159.

33 Rosenberg and Kohler also support Zunz's view and believe that in Tg. 1-2 Chr. is written in a Palestinian Aramaic dialect. See M. Rosenberg, K. Kohler, Das Targum zur Chronik, 72-80, 135-163, 263-278. 
Palestine. ${ }^{34}$ For this reason, this Targum may have been almost completely unknown to medieval scholars. According to Sperber, those who compiled Tg. 1-2 Chr. the Aramaic was the common parlance of the Jews, so they needed an Aramaic translation to understand the Bible. At the same time, they were under the influence of the Greco-Roman civilization that surrounded them and to which they succumbed. This is confirmed, among other things, by the occurrence in the Targums of borrowings of Greek and Latin words ${ }^{35}$ they must have used, which gradually entered the colloquial speech. Such borrowings do not occur in Jewish literature outside Palestine. In addition, this Targum manifests an interest in the toponymy of Palestine, institutions related to Torah study, and the Haggadah, present in the so-called Jerusalem Targum of the Pentateuch (the Fragmentary Targum, but especially in the Targum of Pseudo-Jonathan, which was formerly included in the Jerusalem Targum). ${ }^{36}$

Recently, Leeor Gottlieb ${ }^{37}$ undertook a thorough analysis of the Targum of Chronicles and presented arguments that call for a reevaluation of some of the findings hitherto almost universally taken for granted. It turns out that, contrary to Churgin's claims, there are some elements in $\mathrm{Tg}$. 1-2 Chr. that hint at indicate the time of its composition. Gottlieb's view that $\mathrm{Tg}$. 1-2 Chr. dates from later times than hitherto assumed is supported above all by the dialect, in

${ }^{34}$ According to Le Déaut and Churgin, the author of Tg. 1-2 Chr. was familiar with this Tg., for this is supported by a number of correspondences between the two documents, e.g., $1 \mathrm{Chr}$ 10:3.8 and 1 Sam 31:3.8 (for a more complete list see Le Déaut). On the other hand, there are paraphrases in Tg. 1-2 Chr. which are absent in $\mathrm{TgJ}$, and there are sometimes discrepancies in the translations of the two documents. According to Churgin, at one time there was a Tg. to the Prophets of the Palestinian recension, which the editor of $\mathrm{Tg}$. 1-2 Chr. had before his eyes. Today this document has not survived, only fragments of it have survived, as some additions in Codex Reuchlinianus, often introduced with the words: "Targum Jerusalem."

${ }^{35}$ A list of 57 such words that are used in Tg. 1-2 Chr. is presented by J. Stanley McIvor, The Targum Chronicles, 31-33.

${ }^{36}$ J. Stanley McIvor (The Targum Chronicles, 16) points to the presence in the background of Tg. Ps.-J. especially in those fragments of 1-2 Chr, which have parallels in the Pentateuch, especially in 1 Chr 1-2 (e.g., Tg. Ps.-J. Ex 35:26 with Tg. 1 Chr. 2:18).

${ }^{37}$ L. Gottlieb, Targum Chronicles, 493. 
which the Targum was written, and by its direct dependence on Tg. Ps.-J., and by certain expressions that he attributes to a period later than the 8th century. Tg. 1-2 Chr. was not written in the exclusively Western Aramaic (Palestinian) or exclusively the Eastern Aramaic (Babylonian) language, but in a dialect which weaves Eastern elements into an originally Western outline. This dialect is called by Kaufman "literary late Jewish Aramaic," and it occurs in Tg. Ps.-J., and in many Targums of the Writings. ${ }^{38}$ According to Gottlieb, Targum Chronicles makes secondary use of extensions from Tg. Ps.-J., showing a world, in which the Muslim empire has long been an accomplished fact (1 Chr 1:20.30). He also points to the expressions that support the late date of the origin of this Targum. The mention of the Hungarians, a name which did not exist before the 9th century and which only began to appear in Jewish literature in the 10th century, imposes a terminus post quem several centuries later than hitherto accepted. Moreover, the custom of using two names in relation to the halakhic Midrash to Leviticus (Sifra, Torat Kohanim) is documented in literature only from the ninth century onwards. The detailed compilation of calendar dates ( $1 \mathrm{Chr} 4: 23 ; 12: 33$ ) corresponds to the times after the calendar disputes that took place in the 9 th-11th centuries. It has been established that the Targum of Chronicles shows a degree of linguistic affinity with the kind of the Aramaic found in the medieval piyyutim of the Ashkenazi Jews. ${ }^{39}$

As concerns the setting in life in which the Targum of Chronicles may have been written, in the absence of the presence of the First and Second Books of Chronicles in the Jewish liturgy suggests that it must be sought in at schools ${ }^{40}$ or in a private study, ${ }^{41}$ which, however, is difficult to prove. In this case, the strong emphasis on

${ }^{38}$ Since the late origin of Tg. Ps.-J. has been demonstrated, Tg. 1-2 Chr. must be considered even later. Gottlieb also accepts the late dating of Tg. Ps.-J., and points to Italy in the 12th century as the place of composition of this work.

${ }^{39}$ L. Gottlieb, Targum Chronicles, 494.

40 According to Rosenberg and Kohler, what is meant is some kind of comprehensive teaching activity (umfassenden Lehrthätigkeit), involving the explication of the entire Bible, the centre of which was at bet hammidrash. See M. Rosenberg, K. Kohler, Das Targum zur Chronik, 274-276.

${ }^{41}$ R. Kasher, The Aramaic Targumim, 75-85. 
the Torah study and the praise of those who became students of the Law present in Tg. 1-2 Chr. could be some indication. ${ }^{42}$

\section{Translation strategies and techniques and elements of exegesis in the Aramaic translation}

First of all, the translator's greatest challenge was to render the Hebrew text of the Book of Chronicles into the Aramaic, since it had to be a translation that was clear, unambiguous and comprehensible to the recipients. For this reason, he made certain modifications so that the Targum served not only to edify the addressees, but also to convey elements of a tradition that was still evolving.

The past presented by the Chronicler in the biblical text required a response in the present. Through the selection and portrayal of Israel's traditions, the stereotypical presentation of characters, for example, the presentation of David and Solomon as ideal kings and therefore exemplary figures, provided the opportunity to evaluate past generations, so that the audience of Chronicles could understand their contemporary situation, indicating that their identity is strictly inked to all past generations of Israel. The evaluation of their current situation was intended to elicit an appropriate response. The Chronicler was pointing out that YHWH's protection, which continued through the generations, depended on the conduct of the people. Both in the past and in the situation depicted in Chronicles, Israel was still obliged to practice true worship of YHWH. The recipients of the Chronicler, through his work, were able to know what brought blessings and what brought disasters. They were reminded that any situation could change, depending on whether one sought or turned away from YHWH. The Chronicler, by re-presenting the past, called the nation

${ }^{42}$ I. Kalimi, The Retelling of Chronicles, 159. According to Gottlieb (Targum Chronicles, 495), the author of Tg. Chron was familiar with the Babylonian Talmud and used it as a primary source for his own biblical exegesis. This composite picture attempts to reflect the reality in which our author revolved. He was a rabbinic scholar influenced to varying degrees by the works of the two Jewish academic centres, Palestinian and Babylonian, which is reflected in the language in which he wrote. 
back to the right relationship with YHWH and gave them hope for a blessing.

The message of the Chronicler is taken up by the targumist in a new situation. As in the case of other Aramaic biblical translations, the author of the Targum of Chronicles employed specific translation and exegetical techniques to solve various difficulties of the Hebrew text. Basing on the development of theological concepts in the context of Israel's past and the present of his generation, he introduced extensions and additions into his rendering. ${ }^{43}$

The strategy of adaptation applied by the targumist, that is, of transforming the information contained in the biblical text in order to adapt it to the reader's knowledge, may have resulted from an attempt to harmonise it with other biblical texts. A process of targumization by incorporating haggadic and Midrashic traditions also occurred here. As with the biblical parallels of 1-2 Sam and 1-2 Kgs with 1-2 Chr, there are also many parallels here to other Targums with which the translator of Tg. 1-2 Chr. was familiar. He drew on Tg. 1-2 Sam. and Tg. 1-2 Kgs., but also on the Targums of the Pentateuch, especially in the early narrative parts. The Targum of Chronicles offers many interpretations that are found in the Targums of the Pentateuch, especially in the Targum of PseudoJonathan, primally in the context of worship in the temple. However, some arguments also support the idea that he is drawing from Targum Onqelos, too. ${ }^{44}$ Some parallels with Tg. 1-2 Chr. occur in relation to the Targums of the Writings, e.g., in Tg. Ruth and Tg. Song. ${ }^{45}$ In his translation, the author of Tg. 1-2 Chr. made use of many elements belonging to the rabbinic legacy. He inserted a great deal of haggadic material from rabbinic literature, including institutions and concepts that originated in that milieu, and he presented a number of biblical characters in the manner of Jewish sages. Tg. 1-2 Chr. was thus written in the likeness of previous translations of this type, also in terms of form.

${ }^{43}$ P.V.M. Flesher, B. Chilton, Targums, 257.

${ }^{44}$ J. Stanley McIvor, The Targum Chronicles, 18-21.

${ }^{45}$ P.V.M. Flesher, B. Chilton, Targums, 257. See also. M. Baraniak, Zjawisko targumizacji. 


\section{Basic translation techniques in the Targum of Chronicles}

It should be stressed that, in general the meturgeman faithfully followed the Hebrew text ${ }^{46}$ except where he applied certain changes or added something from himself. ${ }^{47}$ The modifications made by the translator may have been due to textual difficulties ${ }^{48}$ - they mostly concern obscure, unknown, ${ }^{49}$ abstract or ambiguous words or expressions, ${ }^{50}$ which the targumist transformed into intelligible, relevant, concrete and detailed ones. ${ }^{51}$ His updating of various information concerns very often relates to the proper names,

${ }^{46}$ E.g., the targumist renders proper names by means of the corresponding Aramaic term, which overlaps in meaning with the Hebrew term, e.g., in $2 \mathrm{Chr}$ 16:6 the place name msph - "Mizpah," "outlook point, watchtower" is in Tg.: skwt' "Sacutha," "watchtower." In 1 Chr 1:30 the five sons of Ishmael are given related Hebrew Aramaic names, e.g., $d w m h$ - "silence" is Aram. štwq" - "silence," and in 1 Chr 4:28 "Hazar-shual" becomes "Hazartala" (Tg.), with the italicised part of the word being in Hebrew and Aramaic respectively "fox." In some places one Aramaic term replaces two or more Hebrew words. In $2 \mathrm{Chr}$ 20:18 the two Hebrew verbs $q d d$ - "to bow down" and $n p l$ - "to fall" are rendered with one $k r$ - "to bow down." In $2 \mathrm{Chr}$ 20:21 the three Hebrew verbs šyr - "to sing" and hll - "to praise" and $y d h$ - "to confess, acknowledge" are replaced by one šbh - "to praise." This approach is best seen in the use of the Aramaic verb qtl - "to kill," which often corresponds to the Hebrew $\mathrm{hrg}$ - "to kill" (1 Chr 7:21), Hiphil $m w t$ - "to condemn to death" (2 Kgs 25:4), Hiphil $n k h$ - "to strike" (1 Chr 18:5), dqr - "to pierce, to stab" (1 Chr 10:4), hll - "to pierce, to put to death" (1 Chr 10:1), šht - "destroy" (2 Chr 24:23)

${ }^{47}$ J. Stanley McIvor, The Targum Chronicles, 18-21.

${ }^{48}$ E.g., 2 Chr 35:21: „Not against thee do I come today,” Tg.: ,It is not against you that I have come up to wage war - for you are attacking me this day."

${ }^{49}$ E.g., 1 Chr 18:17: ,the Cherethites and the Pelethites," Tg.: "the archers and slingers"; 2 Chr 9:16: "the house of the forest of Lebanon"; Tg.: "the summer-house of the kings" or "the house of the cooling of kings."

${ }^{50}$ E.g., 1 Chr 17:1: „Here, I am dwelling in the house of cedars,” Tg.: "Here I am dwelling in a house which is covered with cedar paneling"; 2 Chr 12:12: "In Judah there have been good things.," Tg.: "To those of the house of Judah he decided to bring good fortune."

${ }^{51}$ E.g., 1 Chr 5:22: „until the exile,” Tg.: "until the exile of Sennacherib, the king of Assyria"; 2 Chr 32:21: "the angel," Tg.: "the angel Gabriel." 
especially the geographical and ethnic terms, ${ }^{52}$ as well as the names of coins. ${ }^{53}$

Additions, extensions and even commentaries on the Hebrew text had various sources. ${ }^{54}$ They may have been derived from the meaning of a cognate word, ${ }^{55}$ or they may have been based on the actual or presumed meaning of a Hebrew word. ${ }^{56}$ Sometimes the targumist used a characteristic technique which consisted in dividing a word into syllables and giving their interpretation. ${ }^{57} \mathrm{He}$ introduced synonymous expressions into his rendering and he gave separate explanations to them. ${ }^{58}$ The extensions may also have originated in another variant of the text. ${ }^{59}$

\section{Changes resulting from the development of theological concepts}

As in other Targums, the doctrinal changes in Tg. 1-2 Ch. mainly concern the concept of God, the relationship between God a man, the mediating role of angels, the fundamental importance of the Torah, but also the phenomenon of prophecy and the respect for

${ }^{52}$ E.g., 1 Chr 18:9 "Hamath," Tg.: "Antioch" or "Hamath,” e.g., Tg. 1 Chr. 18:3; 1 Chr 1:29 „Qedar," Tg.: „Arab.”

${ }^{53}$ E.g., 1 Chr 29:7 "talents,” Tg.: ,centenara.”

${ }^{54}$ J. Stanley McIvor, The Targum Chronicles, 22-24.

${ }^{55}$ E.g., in Tg. 1 Chr 4:15 Caleb's statement refers to his father's name (Jephunneh); in Tg. 1 Chr. 1:19 the statement for Joktan (yqtn) is based on a word that looks similar ( $q t^{\prime}-$ "cut (off)"). In Tg. 2 Chr. 13:5 the mention of the "covenant of salt" leads to an addendum which speaks of making fresh the waters of the sea.

${ }^{56}$ E.g., 1 Chr 1:10: Nimrod from $m r d$ - "rebel"; 1:20: Hazar Maveth - "the courtyard of death."

${ }^{57}$ E.g., in 1 Chr 16:3 each person gets a loaf of bread and špr. The Targumist focuses on its first syllable ' $\breve{s}$ and associates it with the word meaning "six" (which looks quite similar), and when combined with the second syllable ( $p r$ ), which itself means "ox," the result is that everyone got one sixth of an ox!

${ }^{58}$ E.g., 1 Chr 28:2: "My brothers and my people"; Tg.: "my brethren and my people, my brethren the house of Israel, and my people, the proselytes who are in their towns."

${ }^{59}$ E.g., 1 Chr 13:9 has "the threshing floor of Chidon," and the parallel text 2 Sam 6:6 speaks of "the threshing floor of Nakon," which in Tg. 2 Sam. becomes "a place prepared" on the basis of the stem kwn (Nakon) - Tg. 1 Chr. 13:9. 
ancestors and their merits (zěkkut 'ābôt), which leads to the glorification of the greatest biblical heroes. ${ }^{60}$

The Targum of Chronicles clearly emphasises the transcendence and exclusive existence of the one and only God. ${ }^{61}$ To this end, the targumist added texts, in which he extols God's glory and majesty, His power in creation, the deliverance of His people and His sovereign rule over all things, e.g.: "Yours, O Lord, is the greatness, for with great power you created the world, and the might, for you brought our fathers out of Egypt with many mighty acts and brought them across the sea, and you were revealed in splendor upon the mountain of Sinai, with bands of angels, to give the law to your people. You gave victories over Amalek, Sihon, Og and the kings of the Canaanites; in the majesty of your glory you caused the sun to stand still in Gibeon and the moon in the plain of Ajalon, until your people, the house of Israel, were avenged on those who hated them. For all these things are the works of your hand, in heaven and on earth, and you have authority over them and sustain everything which is in heaven and everything which is on earth. Yours, O Lord, is the dominion in the firmament, and you are exalted above all the angels that are in heaven and above all those who are appointed as leaders on earth" (Tg. 1 Chr. 29:11). ${ }^{62}$

The translator of Chronicles, in a manner characteristic of targumism, attempted to portray the relationship between God and a man by using techniques that exclude any direct contact between them. For this purpose, he regularly used the term memra, the basic meaning of which is "word" (from the root ' $m r$ - "to speak"). The occurrence of this term in the text usually emphasises God's action. One of the most common uses of this word is the translation of the phrase "God helped him" or "God was with him" in the sense of a helpful or supportive presence, which is translated in the Targum as follows: "The Memra of the Lord was with him to help him"

60 J. Stanley McIvor, The Targum Chronicles, 24-31. J. Ribera-Florit, Doctrinal Peculiarities, 170-173. Cf. L. Smolar, M. Aberbach, Studies in Targum Jonathan, 129-227.

${ }^{61}$ E. Levine, The Aramaic Version.

62 The italics used in the quotation correspond to the additions made to the Hebrew text by the Aramaic translator. English translation J. Stanley McIvor, The Targum Chronicles. 
(e.g., Tg. 1 Chr. 17:2.8). ${ }^{63}$ In the Aramaic version, despite the rule of speaking at a distance about God's relations with a man, the targumist stressed God's action or His memra for the good of His people, to deliver them, to show them help or to uplift them (Tg. 1 Chr. 17:21; 29,11; Tg. 2 Chr. 28:3).

The Aramaic translator took great pains to not apply the word "God" to be used to refer to anyone or anything else but the Creator of heaven and earth, YHWH, the God of Israel, the Lord of the universe. To this end it excluded any ambiguity or imprecise language by translating the word "God," when it occurs in status absolutus, as the proper Hebrew name of YHWH. ${ }^{64}$ Where the Masoretic text might have suggested the existence of some other deities, the meturgeman usually used the term $t$ ' $w w t$ ' (from the root $t$ " $w w t$ ' - "to lead astray"), which should be translated as "idol," "false god"65 or more rarely the word $d h l t$ ' (from the root $d h l$ - "to fear"), with the meaning "object of fear" or "object of veneration."

${ }^{63}$ In other places Memra seems to act as a personal pronoun, e.g.: "And he repented in his Memra." (Tg. 1 Chr. 21:15). Although there are also places where Memra is used to refer to people, each time as a personal pronoun. In $\mathrm{Tg}$. $2 \mathrm{Chr}$. 16:3 Asa says to Ben-Hadad. Tg. 2 Chr. 32:1 (cf. Tg. 2 Chr. 23:16; 25:19). There are also examples where YHWH acts without the mediation of the Memra, e.g., Tg. 1 Chr. 28:4-5. More on Memra see A. Chester, Divine Revelation, 293-312.

${ }^{64} \mathrm{He}$ does likewise with such juxtapositions as: MT: "house of God" - Tg.: "the sanctuary house of LoRD" (e.g., Tg. 1 Chr. 9:11.13.26.27; Tg. 2 Chr. 3:3; 4:11.19; 5:1.14; 7:5); MT: "ark of God" - Tg.: "ark of LorD” (e.g., Tg. 1 Chr. 13:6.7.14; 15,2; 16:1; Tg. 2 Chr. 1,4); TM: "man of God" - Tg.: "prophet of the LORD" (e.g., Tg. 1 Chr. 23,14; Tg. 2 Chr. 11:2); Where the phrase "seek the LORD" occurs, the targumist introduces the expanded form "seek instruction from before the LORD" (Tg. 2 Chr. 16:12) or "seek the fear of the LORD." (Tg. 1 Chr. 28:9; cf. Tg. 2 Chr. 15:2.15). Some of the terms are replaced in Aramaic by more appropriate terms according to the targumist, e.g., "peace offerings" (šlmym) become "the sacrifices of the holy things" (see Tg. 2 Chr. 30:22; 33:16), and the verb "hear" and "listen" are often replaced by the verb "receive from" (e.g., Tg. 1 Chr. 10:10; Tg. 2 Chr. 10:15.16; 13:4).

65 Among others, 2 Chr 7:19.22; 28:25; 34:25.

${ }^{66}$ See MT 1 Chr. 16:26: "for all the gods of the peoples are things of nought" Tg.: "for all the idols of the peoples are gods which are of no use." 
In similar way, he rendered the passages, where mention was made of people or objects associated with these "idols, false gods." 67

Like all other Targums, Tg. 1-2 Chr. also constantly accentuates the incorporeality of God and seeks to transform anthropomorphisms and anthropopathisms, since neither parts of the body, nor human feelings and emotions, nor any human activities can be attributed to God. This concerns especially the parts of the human body that the Masoretic text assigns to God (hands, ${ }^{68}$ legs, ${ }^{69}$ mouth, ${ }^{70}$ eyes, ${ }^{71}$ ears $^{72}$ ), or the activities that these organs perform (touching, walking, seeing, hearing, etc.). ${ }^{73}$ Although the meturgeman made used of this procedure very often, it sometimes it happened that he was not entirely consistent in doing so. ${ }^{74}$

Moreover, the translator often used the passive voice to express the actions of different parts of the body. ${ }^{75}$ In this context, it is worth mentioning that the Targums employ a specific formula reflecting the verb "to reveal" in the passive - "was revealed"

${ }^{67}$ In MT "altar" (YHWH or pagan) is in Hebrew $m z b h$, in the Targum the term is used only for YHWH altars, while pagan altars are referred to by the term ' $g w r$ ' - "pile of stones," similarly for the Hebrew term khn - "priest," in the Targum it refers only to a priest of YHWH, while the term $k w m r$ ' is used to refer to a pagan priest.

${ }^{68}$ E.g., MT 2 Chr 6:4: "with His hands fulfilled"; Tg.: "by his good will has confirmed it"; 2 Chr 6:15: "with Thy mouth, and hast fulfilled it with Thy hand"; Tg.: "you decided, by your Memra, and by your will you brought it about."

${ }^{69}$ MT 1 Chr 28:2: "and for the footstool of our God"; Tg.: "and for the footstool of the throne of the glory of the LORD."

${ }^{70}$ MT 2 Chr 36:12: "the prophet speaking from the mouth of the LORD"; Tg.: "the prophet, who prophesied to him from the mouth of the Memra of the LORD."

${ }^{71}$ E.g., in reference to the king: 2 Chr 14:1; 1 Chr 13:4 (cf. Tg. 2 Chr. 30:4); see also: 2 Chr. 6:20. But in 2 Chr 16:9 the wording of MT: "the eyes of the LORD look upon the whole earth" remain also in $\mathrm{Tg}$.

${ }^{72}$ See 1 Chr 28:8 MT. But in 2 Chr 6:40; 7:15 the word "ears" remains in Tg.

73 J. Stanley McIvor, The Targum Chronicles, 26-27.

${ }^{74}$ E.g., in 1 Chr 28:19 MT: "All this in writing from the hand of the LoRD," which in the targum does not change. And sometimes it is even added in $2 \mathrm{Chr}$ 25:8.

75 E.g., 2 Chr 34:27: "I heard"; Tg.: "was heard before Me," though subsequently the phrase is also retained: "the LORD said." The verb "hear" is often replaced by the targumist with the phrase "receive from" (e.g., Tg. 2 Chr. 6:23.25.27.30.33).

${ }^{76}$ On the targumic meaning and use of the passive side in $g l$ ' stem, see A. Chester, Divine Revelation, 8-263. 
7:1; cf. its occurrence as an equivalent for other Hebrew verbs, e.g., Tg. 2 Chr. 12:7) ${ }^{77}$ Still another way of highlighting the distance between God and a man is to translate the preposition "to" or "for" from the Hebrew text with qdm - "before" in reference to Lord (e.g., Tg. 2 Chr. 5:13). ${ }^{78}$

Because the targumist was aware of that God was too great and powerful to be described in the earthly terms (Tg. $2 \mathrm{Chr}$. 2:5), or to be spoken of directly, he used an interchangeable phrase Shekinah, when mentioned the presence of YHWH (Tg. $2 \mathrm{Chr}$. 7:10). The issue of the Shekinah's presence in the temple and in Jerusalem is addressed to repeatedly in Tg. 1-2 Chr. On several occasions, the targumist took up the subject of the rituals performed in the temple, its personnel and temple furnishings. Among other things, he introduced a name for the sacrifices offered in the temple, calling them "offerings (of) holy things" - these which were distributed among the people in the number of "one-sixth of an ox and one-sixth of a hin of wine" (Tg. 1 Chr. 16:3). The targumist listed the staff members in charge of the various places in the temple (Tg. $1 \mathrm{Chr}$. 26). He described the furnishings of the temple (Tg. 2 Chr. 4:6).

In the context of the development of theological concepts, it should be noted that, apart from its elaborate angelology, Tg. 1-2 Chr. almost completely omits any eschatological and messianic themes. On the Messiah there is only one enigmatic mention in Tg. 1 Chr. 3:24

In regard to angelology, ${ }^{79} \mathrm{Tg}$. 1-2 Chr. refers to "angels sent by the Lord" ${ }^{80}$ (e.g., Tg. 1 Chr. 21:18.30), who act in His name and according to His will, remaining under His control. The targumist introduces angels in place of the "heavens" (Tg. $1 \mathrm{Chr} 16: 31$ ), and in several cases for God Himself (e.g., Tg. 1 Chr. 17:21). Groups of angels correspond to the heavenly hosts (e.g., Tg. $1 \mathrm{Chr} .12: 23){ }^{81}$

772 Chr 7:12: "the LORD appeared"; 2 Chr 12:7: "the LORD saw."

782 Chr 5:13: "praise the LoRD." See also 2 Chr 32:23-24; 1 Chr 21:8.14; 23:31.

$79 \mathrm{Cf}$. on the angels in the targums to the Pentateuch: M.S. Wróbel, Wprowadzenie, 250-256.

${ }^{80}$ The targumist addresses them with the Hebrew and Aramaic word. $m l$ ' $k$, with one exception - Tg. $1 \mathrm{Chr}$. 16:31 - where there is a borrowed term 'ngly.

811 Chr 12:23; 1 Chr 14:15. 
Angels are also present at Sinai at the handing over of the Law (Tg. 1 Chr. 29:11). The angels Gabriel and Michael, who were sent to destroy the Assyrians, are mentioned by their name (Tg. $2 \mathrm{Chr}$. 32:21; cf. Dan 8:16; 12:1).

According to the concept of God "exalted" presented by $\mathrm{Tg}$. 1-2 Chr., there is the possibility of "knowing" Him, by means of devoting oneself to the study of the Law and its observance. The targumist took great care in his translation to present matters to the audience in such a way that everything would be in conformity to the Law and the Jewish tradition, therefore he repeatedly stated: "as Moses commanded."

The attitude of biblical characters, who were considered as the models by the audience contemporary of the targumist above all, Moses and David - is of the vital importance here. Wherever they are mentioned, extensions are made to the original text. Such additions often indicate the zeal of these figures in learning and observing the Law. Their fame and importance are emphasised by the appended hymns of praise. The descriptions reflect the welldeveloped doctrine of merits winning by pious people. It plays an important role in the Targums, as it does in Talmudic and homiletic literature: the merit of one man (Hebrew: zěkît) benefits another man or the entire community. ${ }^{82}$

Among the main heroes who allow the targumist to link the past of biblical text with the present of his time, so that Israel continues to be blessed by God, are Isaac, Moses and David.

According to the Targums, the merit to have been associated with the offering of Isaac (Tg. Ps.-J. Gen 22:14) that first averted God's wrath against Israel (Tg. 1 Chr. 21:15) and then became the theological foundation for Solomon's building of the temple (Tg. 1 Chr. 3:1). ${ }^{83}$

Moses' virtues and achievements are described in a spectacular way in Tg. 1 Chr. 4:18: "His wife, Jehuditha, brought up Moses after she had drawn him up out of the water. She called his name Jered, because he brought down manna for Israel; chief of Gedor, because he rebuilt the ruins of Israel; Heber, because he united Israel with

82 J. Neusner, ,Zekhut,” col. 2863-2871.

${ }^{83}$ P.V.M. Flesher, B. Chilton, Targums, 257. 
their father who is in heaven; chief of Soco, because he covered the house of Israel with his merit; Jekuthiel, because in his days Israel waited forty years in the wilderness for the God who is in heaven; chief Zanoah, because on his account, God forgave Israel's sins. These names Bithiah, the daughter of Pharaoh, called him by the spirit of prophecy. She became a proselyte, and Mered, who was Caleb, married her, for he had opposed the advice of the spies." The Masoretic text of $1 \mathrm{Chr}$ 4:18 conveys only as much: „His wife Hajehudijah bore Jered the father of Gedor, and Heber the father of Soco, and Jekuthiel the father of Zanoah - and these are the sons of Bithiah the daughter of Pharaoh whom Mered took" (JPS).

The Targum of Chronicles employed a technique corresponding to the Jewish exegesis (cf. b. Meg. 13b) which consists in a particular figure being identified with another figure, often much more significant and distinguished. For the translator, this type of interpretation posed no problem. According to him, for example, a woman pulled Moses out of the water, brought him up and gave him six names: three names of the fathers and three names of the sons referred to in MT. The meaning of the Hebrew roots of each of these names became the starting point for six concise commentaries, in which the targumist extoled the qualities and merits of Moses. At this point, there are striking similarities between his descriptions and b. Meg. 13a and LevR 1:1, where additional virtues and advantages are assigned to Moses in the same way. Moreover, the targumist claimed that the Pharaoh's daughter became a proselyte, and Mered whom he identified with Caleb took her as his wife. The whole extension was probably based on the phrase "Pharaoh's daughter," which brought to mind drawing Moses out of the water and bringing him up, and this in turn led further to recalling his various merits.

This type of technique was also used for other characters appearing in $\mathrm{Tg}$. $1-2 \mathrm{Chr} .{ }^{84}$ For the translator, as for the

${ }^{84}$ E.g., 1 Chr 1:43: Balaam = Laban; 2:7: Karmi = Zimri; 2:19: Miriam = Ephrata; 2:55: Jabes = Otniel; 3:3: Egla = Michal; 4:15: Merem = Caleb; 8:33: Abiel $=$ Ner; 23:16: Shebuel $=$ Jonathan. The intention of the translator was to emphasize the message, and for this purpose he chose persons instead of adjectives. 
commentators of old, it was no problem that there was a temporal gap between the generations mentioned.

Particularly elaborate haggadic traditions occur in the paean to David, to whom the targumist attributes, among other things, great wisdom because of his knowledge of the Law: "These are the total numbers of the warriors who were with David, the warrior, the leader of the camp, sitting on the judgment seat, anointed with holy oil, with all the prophets and wise men round about him. When he went forth to battle he received help from on high; when he sat down to give instruction in the Law, the correct decision came to his mind; select and fastidious, handsome in his appearance and comely in looks, skilled in wisdom, intelligent in counsel, mighty in strength, head of the academy, with a pleasant voice, an outstanding singer, officer in charge of all the warriors, equipped with weapons, carrying a spear on which was hung the sign of the formation of the camp of Judah, going forth on the instruction of the spirit of holiness, he was victorious in battle and with the spear cut down three hundred men slain at the one time" (Tg. 1 Chr. 11:11).

Next to the David's deeds of war, the above passage gives information of his sitting down with the prophets. In another place, the Targum states that David used to get up to study the Law even in the middle of the night (cf. Tg. 1 Chr. 20:5). The targumist often spoke of the prophets, who were referred to as such in the Hebrew text, but also of the others who were called "men of God." In the Targum, these characters are always termed "prophets of the Lord" (Moses in Tg. 2 Chr. 23:14; David in Tg. 2 Chr. 8:14; Shemaiah in Tg. 2 Chr. 11:2; an anonymous person in Tg. 2 Chr. 25:7). Also, a "seer" becomes here "a prophet" (Tg. 2 Chr. 16:7.10), and his "vision" is actually a "prophecy" (Tg. 2 Chr. 32:32). Similarly, whenever the Hebrew text says that "the word of the Lord was

Accordingly, when he says that Balaam is Laban and Karmi is Zimri, he is trying to emphasise that evil is evil, rather than pointing to a number of evil characters as separate examples. All these individuals are merged into one, and the resulting collective entity is the quintessence of evil. By making an equation of the type " $\mathrm{x}=$ $y$," the targumist ascribes to the hero " $x$ " an advantage, defect or attribute of the hero "y," or a value that could be derived from the name of the latter on linguistic grounds: in this way the hero " $x$ " becomes more praiseworthy or condemnable than his "base prototype." 
with...," the targumist added the qualifying term "prophecy" to his rendering (Tg. 1 Chr. 17:3). ${ }^{85}$

It is characteristic of the Targum that the spirit of prophecy is described as one of the sources of inspiration of a group of scholars of the Law: "they were covered with the spirit of prophecy" (Tg. $1 \mathrm{Chr}$. 2:55). The same spirit of prophecy also helps David to draw up the plan and layout of the temple (Tg. $1 \mathrm{Chr} .28: 12)$. Giving in to the spirit of prophecy, allows one to know what would normally be covered up. In this context, one of the most important elements of "prophecy" can be taken to be an understanding of God's wisdom, the recipients of which were the scholars of the Law. In this way, the targumist was in line with the rabbinic principle, also applied in the Talmud, that the prophet has the task of explaining and interpreting the teaching of the revelation that God gave to Moses.

It is also worth mentioning other figures who did not play such a great role in the Masoretic text as Moses and David, yet the targumist accentuated their stature and importance by highlighting their contributions to the life and work of other men of God. These characters are worthy of praise and emulation because of their knowledge and understanding, e.g., Jabes (Tg. 1 Chr. 4:9), ${ }^{86}$ whom the targumist portrayed as the founder of the academy (Tg. $1 \mathrm{Chr}$. 2:55), and Booz, the husband of Ruth, was not only "leader of the sages of the academy of Bethlehem, [...] engaged in (the study of) the words of the Ancient of Days," but also of whose activity he wrote that it contributed to "establish the world" - this man did "build up and restore completely the ruins of the house of Israel, along with the Shekinah of the king of the world, by the service of the Law" (Tg. 1 Chr. 4:22-23). Benaiah, of whom we learn from the Hebrew text to have been David's bodyguard, the targumist featured as a person, whom "David appointed head of the academy, in charge of his disciples" (Tg. 1 Chr. 11:25), and a few verses before he is

85 The passage mentioned above also mentions that David went into battle and thus won victories. In another place the targum states that David got up to study the Law even in the middle of the night (cf. Tg. 1 Chr. 20:5). A different fate befell Saul, who lost the last battle because he "did not seek instruction from before the LORD through Urim and Tummim" (Tg. 1 Chr. 10:14). A similar thing happened to Asa and even Josiah (Tg. 2 Chr. 16:12; 35:23).

86 TM: "He was more respected than his brothers." 
bestowed the honourable title of "master of the Torah" (v. 22). Elsewhere, MT 1 Chr 12:33 says of Issachar's descendants that they possessed the gift of "understanding the times" and knowing what Israel should do, so in the targumist's interpretation they were "the heads of the Sanhedrin: two hundred, with all their brethren, who were putting into practice the decrees of the Law."

\section{Summary}

On the basis of the presented review of translation techniques and elements of Jewish exegesis used in the Targum of Chronicles, it can be concluded that we are dealing with a phenomenon of targumism, for which the books of the Hebrew Bible (mostly 1-2 Sam and 1-2 Kgs) are the starting point and at the same time the point of reference. The late origin of this Targum is confirmed by, among others, its use of the already existing Aramaic translations, above all, the Targum of Jonathan to the Former Prophets (Tg. 1-2 Sam. and Tg. 1-2 Kgs.) and the Targums of the Pentateuch, especially the Targum of Pseudo-Jonathan and the Targum of the Writings (Tg. Ruth and Tg. Song). The harmonisation of their transmission in the Targum of Chronicles indicates that it was written at the time when the above Targums were already known and respected.

The author of Tg. 1-2 Chr. intended to deliver the rendering that would serve as an exegetical support in the private study of the biblical Book of Chronicles. For this purpose, he made his work a kind of anthology of haggadic materials on Chronicles that were scattered in various places in the abundant rabbinic literature, especially in the Babylonian Talmud. Targum Chronicles was written in the Aramaic, however, not because its recipients spoke that language on a daily basis, but because a targum in the Aramaic was the traditional literary genre for the study of the Hebrew Bible

It should be emphasised that the Aramaic translation of the Book of Chronicles testifies not only to the linguistic, but also to the cultural and religious changes, which found expression in a variety of interpretative tendencies. The targumist thus responded to the reader's most important needs by providing a theologically and doctrinally correct interpretation of the Hebrew text. Due to the late date of the origin of this Targum, as well as a result of composing it 
in the specific milieu of bet midrash (a school preparing new experts of the Holy Tradition or a private study of sacred texts), the rendering contains a great deal of haggadic and midrashic traditions, which proves that the author of the Targum was perfectly acquainted with the literary techniques of his predecessors.

The broad historical perspective of Tg. 1-2 Chr., combined with its multiple references to other Targums, allowed the translator to elaborate on the interaction of the past with the present that was reflected in the continuation of the blessing that God promised to Israel in subsequent generations. In his additions, the targumist placed emphasis on the various measures that helped to accomplish this task. In his presentation, one of the principal means that leads to the acquisition of wisdom is the study and observance of the Law. The most important biblical characters, whom the translator portrayed as role models, had previously displayed such an attitude. For the targumist, it was also of the crucial importance to remember the merits of the ancestors, which ensured the continuation of God's blessing over Israel, especially in the context of making individual choices that affected the further fate of individuals and the entire nation.

\section{Bibliography}

Alexander, P.S., Targum, Targumim, in: D.N. Freedman (ed.), The Anchor Yale Bible Dictionary, vol. 6, New York (NY) 1992, 321-331.

Bardski, K, "Świątynia Salomona w Targumie do Pieśni nad Pieśniami 3,7-5,1," Collectanea Theologica 70 (2000) no. 2, 79-92.

Bardski, K., „Niewola babilońska w interpretacji Targumu do Pieśni nad Pieśniami 5,2-6,17," Studia Lovicensia 3 (2001), 25-39.

Bardski, K., „Eschatologia mesjańska w Targumie do Pieśni nad Pieśniami 7,12-8,14," in: W. Chrostowski (ed.), Duch i Oblubienica mówią: „Przyjdź”. Księga Pamiatkowa dla Ojca Profesora Augustyna Jankowskiego OSB $w$ 85. rocznice urodzin, Warszawa 2001, 47-58.

Baraniak, M., "Motyw miasta w Księdze Pieśni nad Pieśniami i jego targumiczną interpretacja," Scriptura Biblica et Orientalia 3 (2011), 209-233. 
Baraniak, M., Zjawisko targumizacji na podstawie Targumu do Pieśni nad Pieśniami. Krytyczna edycja tekstu z manuskryptu M 1106 z analiza egzegetyczno-hermeneutyczna i thumaczeniem, Warszawa 2013.

Chester, A., Divine Revelation and Divine Titles in the Pentateuchal Targumim (Texte und Studien zum Antiken Judentum 14), Tübingen 1986.

Chilton, B. (ed.), Judaic Approaches to the Gospels, Atlanta (GA) 1994. Churgin, P., The Targum to Hagiographa [hebr.], New York (NY) 1945. Chrostowski, W., "M. Baraniak, Zjawisko targumizacji na podstawie Targumu do Pieśni nad Pieśniami. Krytyczna edycja tekstu z manuskryptu M 1106 z analizą egzegetyczno-hermeneutyczną i thumaczeniem, Dom Wydawniczy ELIPSA, Warszawa 2013," Collectanea Theologica 83 (2013) no. 4, 232-238.

Flesher, P.V.M., Chilton B., Targums: A Critical Introduction, Waco (TX) 2011.

Gottlieb, L., Targum Chronicles and Its Place Among the Late Targums (Supplement to Aramaic Studies 16), Leiden-Boston 2020.

Hamilton, V.P., Handbook on the Historical Books, Grand Rapids (MI) 2001.

Kalimi, I., "History of Interpretation: The Book of Chronicles in Jewish Tradition from Daniel to Spinoza," Revue Biblique 105 (1998), 5-41.

Kalimi, I., The Retelling of Chronicles in Jewish Tradition and Literature: A Historical Journey, Winona Lake (IN) 2009.

Kasher, R., The Aramaic Targumim and Their Sitz im Leben (World Congress of Jewish Studies 9), Panel Sessions: Bible Studies and Ancient Near East, Jerusalem 1988, 75-85.

Klein, R.W., "Chronicles, Book of 1-2," in: D.N. Freedman (ed.), The Anchor Yale Bible Dictionary, vol. 1, New York (NY) 1992, 9921001 .

Kuśmirek, A., „Świątynia jerozolimska w targumach,” Collectanea Theologica 79 (2009) no. 2, 65-76.

Kuśmirek, A., „Twój naród będzie moim narodem, twój Bóg będzie moim Bogiem - wyznanie Rut w interpretacji targumu (Rt 1,16-17)," in: W. Linke (ed.), Trud w Panu nie jest daremny (por. 1 Kor 15,58). Studia ofiarowane Księdzu Profesorowi Doktorowi Habilitowanemu Janowi Załęskiemu w 70. rocznicę urodzin, Niepokalanów 2010, 309-324.

Kuśmirek, A., "Księga Nahuma w tradycji targumicznej," Collectanea Theologica 81 (2011) no. 4, 101-120.

Kuśmirek, A., "Aramejska wersja Księgi Amosa,” Collectanea Theologica 85 (2015) no. 4, 177-195. 
Kuśmirek, A., "Księga Rodzaju 1-11 w targumach palestyńskich," Collectanea Theologica 83 (2017) no. 4, 75-104.

Kuśmirek, A., "Jacob's Blessing (Gen 49:1-28) in Targumic Interpretation," Collectanea Theologica 90 (2020) no. 5, 95-122.

Lagarde, P., Hagiographa Chaldaice, Leipzig 1873; reprint Osnabrück 1967.

Le Déaut, R., Robert, J., Targum des Chroniques (Cod. Vat. urb. Ebr. 1), Tome I-II (Analecta Biblica 51), Rome 1971.

Levine, E., The Aramaic Version of the Bible. Contents and Context, Berlin 1988.

McIvor, J. Stanley, "The Targum Chronicles. Translated, with Introduction, Apparatus, and Notes," in: K. Cathcart, M. Maher, M. McNamara, (eds.), The Aramaic Bible: The Targum of Ruth and The Targum Chronicles, vol. II, Collegeville (MN) 1994.

Neusner, J., "Zekhut," in: J. Neusner, A.J. Avery-Peck, W.S. Green (eds.), The Encyclopedia of Judaism. Second edition, vol. IV, Leiden-Boston 2005, col. 2863-2871.

Niedźwiecki, T., "Joseph's Two Garments. Reception of Joseph in Targum Neofiti," Aramaic Studies 14 (2016), 147-183.

Ribera-Florit, J., "Doctrinal Peculiarities of TgChr," in: J. Neusner, A.J. Avery-Peck (eds.), Encyclopedia of Midrash, Leiden 2005, $170-173$.

Rosenberg, M., Kohler, K., "Das Targum zur Chronik," Jüdische Zeitschrift für Wissenschaft und Leben 8 (1870), 274-276.

Selman, M.J., 1 Chronicles: An Introduction and Commentary (Tyndale Old Testament Commentaries 10), Downers Grove (IL) 1994.

Smolar, L., Aberbach, M., Studies in Targum Jonathan to the Prophets, New York (NY) 1983.

Sperber, A., The Bible in Aramaic, IVA, Leiden 1968.

Wróbel, M.S. (transl. and ed.), Biblia Aramejska. Targum Neofiti 1. Księga Rodzaju, vol. 1, Lublin 2014.

Wróbel, M.S. (transl. and ed.), Biblia Aramejska Targum Neofiti 1. Księga Wyjścia, vol. 2, Lublin 2017.

Wróbel, M.S., Wprowadzenie do Biblii Aramejskiej, Lublin 2017. 